\title{
Przegląd metod kształtowania płynności mowy u osób jąkających się
}

\section{Methods to develop speech fluency in stuttering individuals - overview}

\author{
Tomasz Woźniak \\ Uniwersytet Marii Curie-Skłodowskiej, Zakład Logopedii i Językoznawstwa Stosowanego, Lublin \\ Adres autora: Tomasz Woźniak, Uniwersytet Marii Curie-Skłodowskiej, Zakład Logopedii i Językoznawstwa \\ Stosowanego, ul. J. Sowińskiego 17, 20-040 Lublin, e-mail: twozniak@vp.pl
}

\section{Streszczenie}

Prezentowany artykuł zawiera przegląd najważniejszych współcześnie stosowanych typów metod kształtowania płynności mówienia wykorzystywanych w terapii osób jąkających się wraz z omówieniem niektórych z nich, reprezentatywnych dla danego typu. W dyskusji rozważa się wybór najskuteczniejszych form oddziaływania terapeutycznego.

Słowa kluczowe: zaburzenia mowy • jąkanie • terapia osób jąkających się

Abstract

The article provides an overview of the most important types of currently used methods for developing fluency used in the therapy of persons who stutter, along with a discussion of some cases, examples of each type. The discussion considers the selection of the most effective forms of therapeutic impact.

Key words: speech disorders • stuttering • speech therapy

\section{Wstęp}

Na wstępie przyjmijmy definicję jąkania, która określa to zaburzenie mowy w sposób szerszy niż tylko ograniczający do występowania niepłynności mówienia. Jąkanie (ICD-10 F98,5, ICD-9 307,0) jest zaburzeniem płynności mówienia, w którym występują symptomy opisywane na różnych poziomach: komunikacyjnym, psychicznym i neurofizjologicznym. Na poziomie komunikacyjnym objawem dominującym jest patologiczna niepłynność mówienia, polegająca przede wszystkim na blokowaniu, przeciąganiu i powtarzaniu dźwięków mowy. Na poziomie psychicznym zwraca uwagę świadomość występowania zaburzenia, przewidywanie wystąpienia niepłynności i wiążące się $\mathrm{z}$ tym reakcje lękowe o charakterze patologicznym (logofobia). Na poziomie neurofizjologicznym głównym objawem jest wzmożone napięcie mięśniowe w obrębie narządów mowy (spastyczność). Chociaż między opisywanymi symptomami zachodzą sprzężenia zwrotne, to za symptom podstawowy jąkania należy uznać specyficznie patologiczną niepłynność mówienia [1].

Takie rozumienie jąkania implikuje wielokierunkowe oddziaływania terapeutyczne. Metody terapii należy podzielić na główne nurty, zgodnie $\mathrm{z}$ ich oddziaływaniem na różne typy objawów. Będą to:

- metody kształtowania płynności mowy,

- metody psychoterapii i farmakoterapii,

- metody usprawniające czynności fizjologiczne leżące u podstaw mówienia.

Ze względu na wielką liczbę różnych sposobów terapii podejmowane są próby opracowania „przewodników” po najskuteczniejszych metodach terapii, opartych na dowodach klinicznych i statystyce [2]. W literaturze polskiej różne formy terapii osób jąkających omówione zostały w opracowaniach A. Mitrinowicz [3] i Z. Tarkowskiego [4]. Wiele opisanych tam metod ma dziś już tylko znaczenie historyczne.

Prezentowany artykuł zawiera przegląd najważniejszych współcześnie stosowanych typów metod kształtowania płynności wraz z omówieniem wybranych metod, reprezentatywnych dla danego typu.

\section{Przegląd metod kształtowania płynności mowy}

Metody kształtowania płynności mowy w przypadku terapii pacjentów z rozwiniętą postacią jąkania są związane najczęściej z: 
1) rytmizacją mówienia,

2) przeciąganiem samogłosek,

3) wspomaganiem aparaturowym wykorzystującym: echokorekcję - opóźnione słuchowe sprzężenie zwrotne (ang. delayed auditory feedback, DAF), transpozycję częstotliwości mowy (ang. frequency-altered auditory feedback, FAF), maskowanie kontroli słuchowej wypowiedzi (ang. masking-noise auditory feedback, MAF),

4) modyfikacją niepłynności mówienia [5]; choć sama płynność mówienia nie jest celem deklarowanym w tej formie oddziaływań. Celem jest przekształcenie niepłynności patologicznej (spastycznej) w postać niepłynności normalnej (niespastycznej). W efekcie stosowania metody pacjent zyskuje proprioreceptywną kontrolę nad procesem artykulacji, co zmniejsza niepłynność, a niekiedy powoduje pojawienie się całkowitej płynności mowy.

\section{Metody rytmizacji wypowiedzi}

Wśród metod rytmizacji wypowiedzi możemy wskazać trzy główne kierunki oddziaływań. Wszystkie one opierają się na budowaniu i kontroli wypowiedzi za pomocą nadania jej odpowiedniej segmentacji czasowej poprzez zastosowanie określonej struktury rytmicznej, ale proces ten dokonuje się w różny sposób.

Są to:

a) metody wykorzystujące metronom i mowę sylabiczną,

b) logorytmika,

c) metoda oparta na naturalnym rytmie mowy $[6,7]$.

Ad. a) Metody wykorzystujące metronom i mowę sylabiczną. Metody te oparte są na obserwacji, że mowa rozbita na sylaby jest znacznie bardziej płynna. Dodatkowo mówienie dokonuje się w takt metronomu, który ułatwia utrzymanie stałego rytmu.

Sposoby takie wykorzystywane są powszechnie na świecie [4]. Jednak nie opisano dokładnych wskazań co do zastosowania ustawień metronomu i procedur przechodzenia od mowy sylabicznej do posługiwania się wyrazami czy frazami, także wypowiadanymi rytmicznie. Możemy wskazać na propozycję J. P. Brady’ego [4], który prezentuje pięć etapów terapii: 1) mówienie w rytm metronomu stolikowego (wolne), 2) zwiększenie prędkości mówienia, 3) zastąpienie metronomu stacjonarnego przenośnym i mówienie rytmiczne $\mathrm{w}$ różnych sytuacjach o wzrastającym poziomie trudności, 4) analogiczny do poprzedniego, ale bez metronomu, 5) próby wyeliminowania lekkiego jąkania, które powracało od czasu do czasu.

Należy zwrócić uwagę na konieczność przejścia przez dość długi etap mowy sztucznie zrytmizowanej i nienaturalnej, co u wielu pacjentów może wywoływać odrzucenie emocjonalne.

Ad. b) Logorytmika jest metodą stosowana w terapii osób jąkających, która ma doprowadzić do swobody zachowania się i wypowiadania, ale też wykształcenia poprawnej koordynacji artykulacyjno-oddechowej, poprzez wprowadzenie rytmu w zachowania ruchowe pacjentów na podstawie ćwiczeń rytmiczno-muzycznych (droga od rytmu w melodii, poprzez rytm w ruchu do rytmu w mowie). Metodę tę w Polsce opracowała A. Rozentalowa [8] a rozwijała E. Kilińska-Ewertowska [9]. Schemat ćwiczeń u Rozentalowej jest następujący:

1) zbiorowe czytanie tekstu,

2) trzykrotne wysłuchanie partii muzycznej,

3) ćwiczenia ruchowo-słowne przy akompaniamencie muzyki,

4) słuchanie partii muzycznej,

5) interpretacja tekstu.

Należy zwrócić uwagę, że zjawiskom rytmizacji wypowiedzi może towarzyszyć w tym wypadku efekt zwolnienia wypowiedzi (przeciągania samogłosek), co dodatkowo podnosi jej płynność. Metoda ta rzadko jest używana jako metoda wiodąca w terapii osób z zaawansowanym jąkaniem. Jej stosowanie ogranicza się do zajęć z dziećmi jąkającymi się w stopniu lekkim i umiarkowanym.

Ad. c) Metoda Z. Engiel [6,7] jest metodą kształtowania płynności mowy na podstawie naturalnego rytmu mowy. Celem i wzorcem metody jest od początku mówienie o prawidłowym przebiegu, to znaczy polega ona na koordynacji początku wydechu ze startem czynności fonacyjnych i artykulacyjnych, które są kontynuowane przez czas trwania jednej grupy rytmicznej (frazy), czas wyznaczany przez trwanie normalnego wydechu. Dąży się do osiągnięcia ciągłości wymówieniowej w obrębie jednej grupy rytmicznej, następnie pracuje się nad regularnym następstwem fraz. W metodzie wyróżniane są dwa typy ćwiczeń: 1) ćwiczenia startu mowy,

2) ćwiczenia toku mowy.

Koordynacja między oddychaniem, fonacją a artykulacja jest osiągana przez wykorzystanie odpowiednich, umownych ruchów rąk (głównie ręki wiodącej), które kontrolują i koordynują przebieg wypowiedzi. Brak jest w tej metodzie ogniw pośrednich wymagających mówienia wolniejszego i sztucznie zrytmizowanego, co czyni ją bardzo atrakcyjną dla pacjentów, ponieważ wypowiedzi od początku nie odbiegają od normalnego mówienia. Metoda ta jest przeznaczona dla osób z zaawansowanym jąkaniem.

\section{Metody przedłużania czasu realizacji samogłosek}

Historycznie metody mowy przedłużonej (ang. prolonged speech) czy też przedłużania samogłosek ustnych reprezentuje w Polsce sposób terapii opracowany przez S. Wilczewskiego [10]. Należy jednak podkreślić, że podobne sposoby są bardzo popularne i używane w różnych krajach, niekiedy stanowią podstawę pracy nad płynnością wypowiedzi - np. w największym brytyjskim ośrodku terapeutycznym The Michael Palin Centre. Polegają zwykle na przejściu od mówienia w tempie 1 sylaba na 1,5 sekundy, a więc bardzo wolnego, do normalnego tempa mówienia, to jest 4-5 sylab na sekundę [11].

Na ten typ metod składają się techniki terapeutyczne, których celem jest przedłużenie czasu artykulacji głosek otwartych - samogłosek ustnych (czasem niektórych półotwartych, np. m). Przedłużenie czasu trwania tych głosek w naturalny sposób wiąże się ze zwolnieniem tempa mówienia i uaktywnieniem proprioreceptywnej kontroli wypowiedzi. Zjawiska te $\mathrm{w}$ znaczącym stopniu wpływają na poprawę płynności wypowiedzi, prawdopodobnie ze 
względu na zmniejszenie czasowych wymagań dotyczących organizacji motorycznej wypowiedzi [12].

Metoda S. Wilczewskiego [10] wychodzi od umiejętności przedłużania samogłosek w śpiewie. Następnie efekt ten stopniowo przenosi się do wypowiedzi nieśpiewanych. Opracowana metoda zakłada trzymiesięczny, intensywny trening płynności mowy, także przy wykorzystaniu ćwiczeń delikatnego startu mowy, przy stałym, aktywnym uczestnictwie osoby towarzyszącej pacjentowi w czasie ćwiczeń. Ćwiczenia, wykonywane przed lustrem, obejmują cały cykl zadań, począwszy od powtarzania, poprzez czytanie, opowiadanie (obrazka, tekstu, swobodnej narracji), aż po naturalną rozmowę. Wykorzystuje się w tej metodzie również techniki usprawniające motorykę narządów mowy, jak również szereg zaleceń psychoterapeutycznych i pedagogicznych, mających zmniejszyć lękowe reakcje pacjenta i obniżyć napięcie mięśniowe (te omawiam jako metody usprawniające czynności fizjologiczne leżące u podstaw mówienia). Zaleca się regularny tryb życia, zapewnienie spokoju w otoczeniu pacjenta, ograniczenie uprawiania sportu i oglądania telewizji. Wiele ćwiczeń pacjent i terapeuta (lub osoba towarzysząca) wykonują razem, co daje efekt podobny do zastosowania echokorektora.

Ostatnio techniki stosowane w metodzie: technika przedłużonego mówienia (TPM) i technika delikatnego startu mowy (TDSM) zostały przywołane i szerzej omówione w publikacji M. Chęćka i współautorów [13]. Od lat techniki te $\mathrm{z}$ powodzeniem wykorzystywane są $\mathrm{w}$ autorskim programie terapii opracowanym przez M. Chęćka [14].

Warto wspomnieć także interesujące próby zwolnienia nie całej wypowiedzi, ale przejść między głoskami dźwięcznymi i bezdźwięcznymi dokonywane za pomocą komputera. Wedle niektórych badaczy rdzeń niepłynności w jąkaniu stanowi niezdolność do szybkiego przełączania pracy fałdów głosowych z pozycji "głoska dźwięczna” do pozycji "głoska bezdźwięczna”. Za pomocą komputerowych programów terapeutycznych jąkający starają się spowolnić tę część mówienia bez spowolnienia innych części, utrzymując w ten sposób naturalne brzmienie mowy [15].

\section{Metody wykorzystujące wspomaganie aparaturowe}

Wśród metod wykorzystujących wspomaganie aparaturowe w terapii osób jąkających najczęściej należy wymienić: a) echokorekcję,

b) transpozycję częstotliwości mowy,

c) maskowanie.

Oprócz tego ciekawe są próby wykorzystywania sprzężenia zwrotnego (biofeedback) z wykorzystaniem elektromiografii (EMG), dokonywane za pomocą komputera. W metodach tych EMG sprzężona z programem komputerowym obrazuje pacjentowi poziom napięcia mięśniowego i pozwala na jego redukcję, co poprawia płynność mowy [16].

Ad. a) Echokorekcja. Wśród metod wykorzystujących wspomaganie aparaturowe najbardziej znane są te, które opierają się na opóźnionym słuchowym sprzężeniu zwrotnym (DAF). W efekcie tym, opisanym przez B. S. Lee [17], bazowano na obserwacji, że w momencie odbioru własnej wypowiedzi z nieznacznym nawet opóźnieniem (zwykle między 0,1 a 0,3 sekundy) mowa ulega spowolnieniu, a u jąkających niepłynność może nawet zaniknąć. Zjawisko to bez wątpliwości potwierdza udział obwodu słuchowej kontroli wypowiedzi w powstawaniu niepłynności.

Powyższe obserwacje stały się podstawą opracowania echokorektorów mowy - specjalnych urządzeń, które pozwalają na sztuczne, precyzyjnie regulowane opóźnienie czasu słyszenia własnej wypowiedzi. W obecnej chwili przy wykorzystaniu odpowiedniego oprogramowania echokorektorem może stać się każdy komputer czy telefon komórkowy.

W Polsce najbardziej znana jest metoda „Echo” opracowana przez B. Adamczyka $[18,19]$. W metodzie tej wedle ostatecznych ustaleń optymalny czas opóźnienia własnego „echa” wynosi $0,1 \mathrm{~s}$ lub nawet poniżej tej wartości. Tempo mówienia jest wówczas zbliżone do naturalnego, a niepłynność pozostaje w granicach normy. Postępowanie terapeutyczne w metodzie „Echo” jest podzielone na trzy etapy: 1)trening płynności mowy za pomocą echokorektora w gabinecie,

2)budowanie płynnej, wolniejszej wypowiedzi z „echem zapamiętanym" (bez echokorektora) w sytuacji łatwej emocjonalnie,

3)mówienie $z$,echem zapamiętanym” w sytuacji trudnej emocjonalnie.

W kontekście zastosowania echokorekcji należy też wymienić technikę mówienia chóralnego, która również prowadzi do ograniczenia niepłynności mówienia. Poza występującym w tym przypadku zwolnieniem tempa mowy rozważa się także możliwość wykorzystania przez mózg pacjenta informacji docierającej drogą słuchową (od współmówiącego), która funkcjonalnie kompensuje deficyt połączeń między obszarami odpowiedzialnymi za przygotowanie i realizację mowy [12].

Ad. b) Transpozycja częstotliwości mowy. Metody te opierają się na zjawisku zmiany częstotliwości sygnału mowy w autokontroli słuchowej (FAF lub AAF - ang. altered auditory feedback) [20]. Zmiana częstotliwości sygnału mowy, dokonywana za pomocą specjalnego urządzenia, polega głównie na obniżeniu częstotliwości. Zjawisko to powoduje poprawę płynności mowy, co można interpretować jako poprawę autokontroli słuchowej, poprzez aktywację przewodnictwa kostnego.

Popularne staje się łączenie efektu transpozycji częstotliwości (transpozycji widmowej sygnału mowy) z opóźnionym słuchowym sprzężeniem zwrotnym w urządzeniach zwanych „cyfrowymi korektorami mowy” (ang. digital speech aid, DSA) [21]. Takie zminiaturyzowane urządzenia stanowią doraźną pomoc w różnych sytuacjach komunikacyjnych. Brak jest jednak w literaturze dobrze opisanych procedur stosowania tych urządzeń.

Ad. c) Maskowanie wypowiedzi. Metody określane terminem "maskowanie” polegają na obniżeniu autokontroli słuchowej poprzez zagłuszenie szumem lub innymi dźwiękami sygnału wypowiedzi osoby jąkającej się. Dokonuje się tego poprzez wykorzystanie aparatów zagłuszających zwanych "maskerami”. Do ucha wiodącego lub obuusznie 
podawany jest przez słuchawki dźwięk zagłuszający o zróżnicowanym indywidualnie natężeniu, w częstotliwościach dźwięków mowy (np. 50-60 dB, 50 Hz). Zagłuszenie autokontroli słuchowej powoduje u większości jąkających się zwiększenie płynności wypowiedzi [4].

Efekt ten potwierdza udział kontroli słuchowej w powstawaniu niepłynności. Prawdopodobnie poprawę płynności w czasie „maskowania” można wytłumaczyć poprzez fakt przejęcia kontroli nad motoryką przez obwód proprioreceptywny, który działa prawidłowo. Legendarna autoterapia Demostenesa, który powtarzał trudne wyrazy, trzymając małe kamienie w ustach, stojąc nad brzegiem morza (kombinacja zwolnienia mówienia za pomocą metody mechanicznej i zagłuszania wywołanego szumem morza), da się objaśnić w podobny sposób.

\section{Metody modyfikacji niepłynności mówienia}

Metody te wywodzą się z programu usuwania jąkania zaawansowanego Ch. Van Ripera [5]. Celem ich jest nie tyle zastąpienie niepłynnego mówienia mową całkiem płynną, ile raczej zamiana spastycznej, pełnej powtórzeń, bloków i dźwięków wtrąconych niepłynnej wypowiedzi pacjenta na wypowiedź z niepłynnością polegającą na niespastycznych przeciągnięciach dźwięków, a także na redukcji lęku związanego z jąkaniem. Pozwala to pacjentowi na sprawną komunikację, a czasami prowadzi do całkowitego usunięcia jąkania. W różnych modyfikacjach są to metody często stosowane w Stanach Zjednoczonych i wielu krajach europejskich [22].

Program Ch. Van Ripera realizowany jest w sześciu etapach (MIDVAS: Motivation, Identification, Desensitization, Variation, Approximation, and Stabilization).

1) Motywacja (motivation): ten etap polega na wyznaczeniu celu terapii, możliwych dróg osiągnięcia celu i rozbudzeniu w pacjencie nadziei, że jego mowa ulegnie poprawie.

2) Identyfikacja (identification): na tym etapie dokonywana jest analiza wszystkich objawów jąkania, bez unikania go. Pacjent zyskuje bardzo dużą samoświadomość objawów własnego zaburzenia.

3) Desentyzacja - odczulanie (desentization): jest etapem, na którym następuje zmiana nastawienia emocjonalnego do jąkania i wzrost odporności na lęk, frustracje $\mathrm{i}$ inne negatywne emocje związane $\mathrm{z}$ jąkaniem. Pacjent uczy się kontrolować emocje związane z jąkaniem.

4) Modyfikacja (variation): polega na wprowadzaniu procedur „płynnego jąkania”, to jest zastępowania niepłynności spastycznej przez niepłynności normalne - np. niespastyczne przeciągnięcia dźwięków.

5) Zbliżanie się (approximation): jest etapem, na którym wprowadza się nowy sposób mówienia w różne sytuacje komunikacyjne i rozwija się umiejętności proprioreceptywnej kontroli wypowiedzi, przy ograniczeniu lub ignorowaniu słuchowej kontroli wypowiedzi.

6) Stabilizacja (stabilization): wiąże się z całkowitym przerzuceniem odpowiedzialności za kontynuowanie terapii na pacjenta. Pacjent ustala własny program terapeutyczny, który musi wykonywać codziennie przez dłuższy czas (do 2 lat). W ten sposób automatyzują się nawyki nowego sposobu mówienia.

\section{Dyskusja}

Podejmując się oceny skuteczności opisanych wyżej metod kształtowania płynności mówienia, należy stwierdzić, że: 1) Nie ma do tej pory obiektywnego, opracowanego na podstawie metod statystycznych i opartego na klinicznych dowodach rankingu skuteczności opisanych metod, rankingu, który poza oceną poziomu płynności uwzględniałby także:

a) opinie pacjentów dotyczących ich zadowolenia ze stosowanych form pracy,

b) utrzymywanie się efektów terapii w odległym terminie od jej zastosowania.

2) Osiągnięcie płynności jest możliwe za pomocą różnych metod, zaś ocena ich skuteczności może być skrajnie subiektywna.

3) Uzyskanie płynności mówienia w trakcie terapii jest możliwe stosunkowo szybko - za pomocą wspomagania aparaturowego nawet podczas pierwszego spotkania, za pomocą innych metod zwykle do trzech miesięcy, co nie oznacza trwałego usunięcia jąkania. Ze względu na kompleksowy charakter zaburzenia (interakcja czynników biologicznych, psychicznych i społecznych) pierwszym problemem po uzyskaniu płynności jest przeniesienie tego efektu w codzienne sytuacje komunikacyjne, drugim staje się utrzymanie stanu poprawy płynności mówienia, połączone ze wzrostem zadowolenia z życia pacjenta.

Na przykład w ocenie skuteczności metod przedłużonego mówienia [23] odnotowuje się, że zaraz po zakończeniu terapii zadowolonych jest $95 \%$ osób, przy czy odsetek ten spada do $43 \% \mathrm{w}$ odstępie roku do dwu lat. Występowanie objawów niepłynności przy użyciu tych metod spada średnio z poziomu $15-20 \%$ do $1-2 \%$ w czasie terapii [11].

Oceny skuteczności dokonam zatem na podstawie własnego, ponaddwudziestoletniego doświadczenia w pracy $\mathrm{z}$ pacjentami jąkającymi się i analizy literatury przedmiotu.

Po pierwsze za niezadowalające $\mathrm{z}$ punktu widzenia pacjenta należy uznać metody wymagające długiego okresu mowy sztucznej: sztucznie zrytmizowanej (mowa sylabiczna) lub spowolnionej. Takie sposoby mówienia są nienaturalne i często bywają odrzucane emocjonalnie przez pacjentów, co kończy się niepowodzeniem całej terapii.

Po drugie metody wspomagania aparaturowego, choć przynoszą ewidentną poprawę płynności w krótkim czasie, jeżeli nie zostaną włączone w inne, kompleksowe odziaływania terapeutyczne, można postrzegać jako protezowanie pacjenta i uznać za niewystarczające - nie prowadzą one bowiem do trwałej zmiany, to znaczy stałej poprawy płynności mówienia. Mogą stanowić one jednak cenne uzupełnienie warsztatu logopedy i znaleźć zastosowanie na początku terapii - jako czynnik motywacyjny lub w jej późniejszej fazie - jako doraźna pomoc w mówieniu podczas wprowadzania w praktykę dnia codziennego innych technik kontroli płynności, szczególnie w trudnych sytuacjach komunikacyjnych.

Duże nadzieje można natomiast wiązać z dalszym rozwojem programów komputerowych wykorzystujących skojarzone, polimodalne oddziaływania, oparte na sprzężeniach 
zwrotnych: słuchowych (DAF, FAF, MAF, elektroniczne modelowanie percepcji słuchowej poprzez przedłużanie niektórych parametrów ciągu fonicznego), czuciowych (EMG), ruchowych i wzrokowych. Mogą one doprowadzić do znacznego ułatwienia nauki kontroli wypowiedzi oraz upowszechnienia form terapii stosowanych obecnie tylko w próbach eksperymentalnych.

Po trzecie za skuteczne w praktyce terapeutycznej należy uznać techniki modelujące zjawiska rytmiczno-czasowej kontroli wypowiedzi bazujące na wykorzystaniu układu motorycznego - metoda Z. Engiel. W mojej ocenie skuteczność tej metody jest wysoka nie tylko poprzez koordynację fizjologicznie prawidłowego przebiegu mówienia, lecz także dzięki segmentacji ciągu fonicznego na frazy zgodne $\mathrm{z}$ naturalnym rytmem mowy, co ułatwia programowanie i autokontrolę wypowiedzi. Nie bez znaczenia jest prawdopodobnie również zaangażowanie ręki wiodącej, stymulującej obszar ruchowy dominującej półkuli mózgu (głównie: prawa ręka - lewa półkula).

Rytm mówienia [24] można zdefiniować jako okresowe powtarzanie się podobnie długo trwających i identycznie uporządkowanych procesów, połączonych w jedną całość szczytem dynamicznym. Następujące po sobie frazy nie muszą być jednakowe, ale przeważa tendencja do regularnego, uporządkowanego w czasie następstwa przycisku i braku przycisku. Rytm mówienia należy wiązać właśnie z regularnym czasowo następstwem fraz. Zjawiska rytmiczne zyskują nowy wymiar w świetle badań
E. Szeląg [25], w których wiąże się je bardzo wyraźnie z czasowymi aspektami funkcjonowania układu nerwowego człowieka, percepcją, programowaniem wypowiedzi na poziomie centralnym, a także interpretacją poznawczą świata.

Po czwarte warto podkreślić wartość aktywacji kontroli proprioreceptywnej wypowiedzi, która w przypadku zaburzeń kontroli słuchowej może stanowić podstawę płynnej mowy. Nauka „wyczuwania” momentów niepłynności pozwala na łagodne zwolnienie ruchu w początkowej fazie powstawania niepłynności i utrzymanie płynności wypowiedzi [5].

W konkluzji należy przyjąć, że dalszy rozwój terapii osób jąkających się w zakresie płynności mowy będzie uwzględniał wykorzystanie technologii komputerowych, oddziaływania percepcyjne oraz polimodalne sprzężenia zwrotne, których celem powinno być ustalenie prawidłowego, naturalnego rytmu wypowiedzi, aktywacja propriorecptywnej kontroli wypowiedzi i/lub modyfikacja kontroli słuchowej. Nowe metody powinny być przyjazne dla pacjenta i możliwe do stosowania poza gabinetem terapeutycznym.

Artykuł powstał $w$ zwiazku $z$ realizacja projektu „Zintegrowany system narzędzi do diagnostyki i telerehabilitacji schorzeń narzadów zmysłów (słuchu, wzroku, mowy, równowagi, smaku, powonienia)" wspólfinansowanego przez Narodowe Centrum Badań i Rozwoju w ramach Programu STRATEGMED.

\section{Piśmiennictwo:}

1. Woźniak T. Standard postępowania logopedycznego w przypadku jąkania. Logopedia, 2008; 37: 227-34.

2. Oonk L, Pertijs M. The Dutch evidence-based guideline for the management and treatment of stuttering. Referat wygłoszony w ramach $9^{\text {th }}$ CPLOL Congress, May 8-9, Florence, Italy. Book of Abstracts, 2015; s. 64.

3. Mitrinowicz A. Jąkanie. Przyczyny i leczenie. Warszawa: PZWL; 1952.

4. Tarkowski Z. Jąkanie, zagadnienia etiologii, diagnozy, terapii i prognozy. Warszawa: Wydawnictwo ZSL; 1987.

5. Van Riper Ch. The nature of stuttering. New Jersey: Englewood Cliffs; 1971.

6. Engiel Z. Próba opracowania systemu ćwiczeń logopedycznych w rehabilitacji jąkania cz I. Zagadnienia Wychowawcze a Zdrowie Psychiczne, 1976; 6: 60-63.

7. Engiel Z. Próba opracowania systemu ćwiczeń logopedycznych w rehabilitacji jąkania cz. II-IV. Zagadnienia Wychowawcze a Zdrowie Psychiczne, 1977; 1: 79-80, 2: 81-84, 3: 70-71.

8. Rozentalowa A. O logorytmice. Logopedia, 1971; 10: 116-26.

9. Kilińska-Ewertowska E. Badania nad zastosowaniem ćwiczeń muzyczno-ruchowych w rehabilitacji dzieci z zaburzeniami mowy. Gdańsk: Wydawnictwo PWSM; 1981.

10. Wilczewski S. Teoretyczne założenia i metoda usuwania jąkania. Logopedia, 1967; 7: 105-12.

11. Boberg E, Kully D. Long-term results of an intensive treatment program for adults and adolescents who stutter. J Speech Hear Res, 1994; 37: 1050-59.

12. Sommer M, Koch M, Paulus W, Weiller C, Buchel C. Disconection of speech-relevant brain areas in persistent deveopmental stuttering. Lancet, 2002; 8/3: 380-83.
13. Chęciek M, Bijak D, Kamińska D. Jąkanie. Skuteczne techniki płynnego mówienia, TPM i TDSM w Zmodyfikowanym Programie Psychofizjologicznej Terapii Jąkających się. Część 1. i 2. Gdańsk: Wydawnictwo Harmonia; 2014.

14. Chęciek M. Jąkanie - diagnoza, terapia, program. Kraków: Oficyna Wydawnicza „Impuls”; 2007.

15. Ingham RJ, Kilgo M, Ingham JC, Moglia R, Belknap H, Sanchez T. Evaluation of a stuttering treatment based on reduction of short phonation intervals. J Speech Lang Hear Res, 2001; 44: 1229-44.

16. Craig A, Hancock K, Chang E, McCready C, Shepley A, McCaul A i wsp. A controlled clinical trial for stuttering in persons aged 9 to 14 years. J Speech Hear Res, 1996; 39: 808-26.

17. Lee BS. Effects of delayed speech feedback. J Acoust Soc Am, 1950; 22: 639-40.

18. Adamczyk B. O możliwości prowadzenia na terenie szkoły ćwiczeń rehabilitacyjnych z jąkającym się przy pomocy aparatu wytwarzającego echo. Logopedia, 1960; 1: 19-23.

19. Adamczyk B. Terapia jąkania metoda „Echo”. W: Gałkowski T, Tarkowski Z, Zaleski T. Diagnoza i terapia zaburzeń mowy. Lublin: Wydawnictwo UMCS; 1993, s. 141-55.

20. Lincoln M, Packman A, Onslow M. Altered auditory feedback and the treatment of stuttering: a review. J Fluency Disord, 2006; 31(2): 71-89.

21. Roland-Mieszkowski M, Czyżewski A. Kostek B. DSA (Digital Speech Aid) - a new device to decrease or eliminate stuttering. Referat w ramach: The $1^{\text {st }}$ World Congress on Fluency Disorders, August 8-12, Munich, Germany; 1994. 
22. Dell CW. Terapia jąkania u dzieci w młodszym wieku szkolnym. Podręcznik dla logopedów. Kraków: Oficyna Wydawnicza „Impuls”; 2008.

23. Craig A, Calver P. Following up on treated stutterers: studies of perceptions of fluency and job status. J Speech Hear Res, 1991; 34: 279-84.
24. Woźniak T. Niepłynność mówienia. W: Grabias S, Kurkowski M. Logopedia. Teoria zaburzeń mowy. Lublin: Wydawnictwo UMCS, 2012; 549-64.

25. Szeląg E. Nowe metody terapii wyzwaniem XXI wieku. Logopedia, 1999; 26: 215-24. 